\title{
Urban Geomorphology of Darbandikhan District Using GIS \& RS Iraqi Kurdistan Region
}

\author{
Sarkawt Ghazi Salar \\ Lecturer, Department of Geography, College of Education, University of Garmian \\ e-mail: sarkawt.Ghazi@garmian.edu.krd
}

\begin{abstract}
Geomorphology is an important aspect for urban planning, which gives an idea about the variations in landscape/landform and indirectly facilitates in evaluating the resources of an area. In the present paper, an attempt has been made to study the geomorphic implications on urban expansion of Darbandikhan district. The study area is in Iraqi Kurdistan Region. It covers an area about $\left(546.02 \mathrm{~km}^{2}\right)$ with nearly $(150 \mathrm{~km})$ perimeter. For detailed study, multi-temporal satellite imageries of Landsat 3, 5, 7, 8 and QuickBird were used with the aid of ArcGIS-10.2.2 and Global Mapper 13 software to compile and create database that provided a visual and historical perspective of the urban expansion and practiced in the study area for the past 46 years from 1971 to 2017. Progressive urban mapping in correlation with different thematic maps of lithology, geomorphologic units (landforms), drainage density, elevation, slope gradient and slope aspect delivers the baseline information for the planner and decision makers to observer/monitor and predict the patterns and future trends of urbanization. The rate of urban growth of Darbandikhan town is $1.2 \mathrm{~km}^{2} /$ decade and at 2028 the total suitable potential area, at west of the town, will be consumed and change to townscape if the town expansion growth rate continued in its behavior. Hence geomorphological maps along with other thematic maps are predictive techniques to better future forecast of urban growth that can delineate suitable area for urban development and planning of the Darbandikhan town within the district's administrative boundary.
\end{abstract}

Keywords: Urban Geomorphology, Darbandikhan, Kurdistan, Remote Sensing and GIS

\section{Introduction:}

Geomorphology is one of the basic policies of urban planning, as a result of this, issues of cities need geomorphological planning (Adeli and Khorshiddoust, 2011). Urban geomorphology is an important topic in geomorphology that study the influence of geomorphology on urban growth and expansion, which shows the interaction between a part of nature and human activities. Urban geomorphology examines the geomorphic constraints on urban development (Cooke, 1984) and the suitability of different landforms for specific urban uses; the impacts of urban activities on Earth surface processes, especially during construction; the landforms created by urbanization, including 
land reclamation and waste disposal; and the geomorphic consequences of the extractive industries in and around urban areas (McCall et al. 1996) in Goudie (2004). In urban geomorphology man acts as physical process to change the natural terrain to cityscape. Urban geomorphology is the surface component of urban geology and forms the important subfield of environmental geology (Mohapatra et al., 2014). The original founders of towns and cities carefully chose their sites for defensive, strategic, resource exploitation, navigation or cultural reasons. Urban construction involves removal of the natural vegetation cover and excavation of the topsoil and often much of the underlying weathered rock and bedrock layers (Goudie, 2004). Remote sensing and GIS techniques are an excellent practical and economical tool to study the urban expansion and geomorphological analysis. They are capable for drawing thematic maps, analyzing, interpreting, planning and decision making.

Darbandikhan district is located about $117 \mathrm{~km}$ east of Kirkuk city and 51 $\mathrm{km}$ southeast of Sulaimaniyah City. It covers an area more than $\left(546 \mathrm{~km}^{2}\right)$ with nearly $(150 \mathrm{~km})$ perimeter. It lie between latitudes $34^{\circ} 58^{-}-35^{\circ} 16^{-} \mathrm{N}$ and longitudes $45^{\circ} 29^{-}-45^{\circ} 56^{-} \mathrm{E}$ within the semi - arid region (Figure, 1). The aims of the present study are; (1) to reveal the annual rate and direction of urbanization growth; and (2) to show the effect of geomorphology on urbanization expansion and growth.

\section{Methods and Materials:}

This work has been done based on available data about the study area. The work was carried out in different stages which included data collection, field work and office work with the aid of GIS and several types of data, which were used in the study area such as Digital Elevation Model (DEM) and satellite images of Landsat (Table 1). The Landsat images are downloaded from the U.S. Geological Survey's (USGS) Earth Resources Observation and Science (EROS) Center. All Landsat images, during earlier stages, were reorganized, processed by the author using band combination, stretching and equalization to prepare images and help in better detection of urban area for the following time spans: 1973, 1980, 1990, 2000, 2010 and 2017, represented by mapping and analyzed to produce the final information presentation and mapping for different spatial interpretations like urban change for the past 46 years and geomorphological factors including elevation, slope, drainage system and geomorphologic units. A geomorphological map of the area had been prepared by the author, depending on ITC geomorphological survey system by visual interpretation of satellite images for recognizing the geomorphological units that deals with color, tone, shape, size, pattern, texture, site and association with field work verification. The software that have been used in this study were; Global Mapper 13 for drawing topographic profiles and ArcGIS10.2.2 for drawing the thematic maps and geological cross section. 


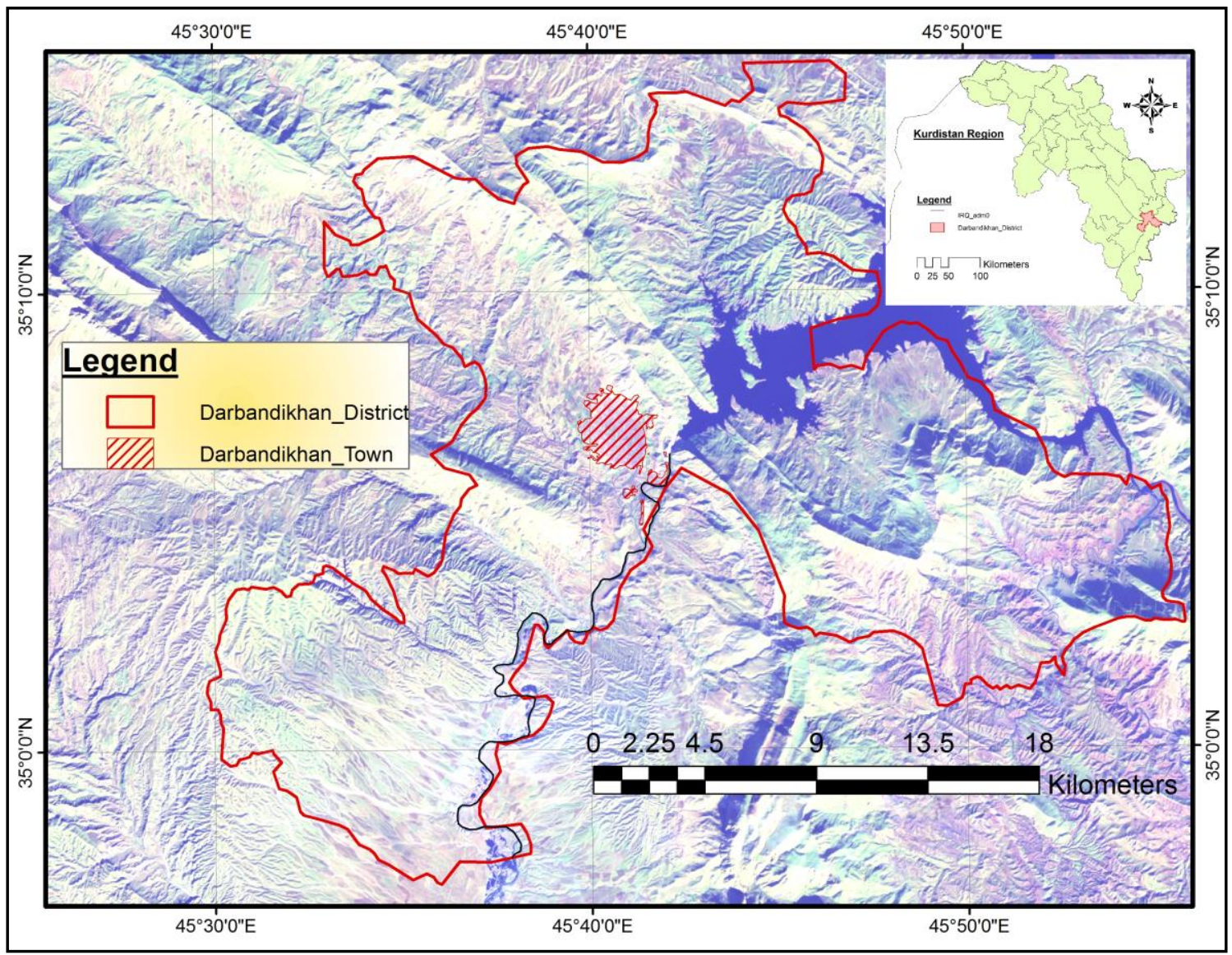

Figure 1: Location of the study area.

Table (1): Collected data and information

\begin{tabular}{|c|l|c|l|c|}
\hline S. No. & \multicolumn{1}{|c|}{ Data } & $\begin{array}{c}\text { Spatial } \\
\text { Resolution }\end{array}$ & \multicolumn{1}{|c|}{ Purpose } & Year \\
\hline 1. & DEM from ASTER image & $30 \mathrm{~m}$ & $\begin{array}{l}\text { Elevation, Drainage System, Slope, } \\
\text { Slope Aspect, Topographic Profiles, }\end{array}$ & \\
\hline 2. & Geological Map & $1: 250000$ & Reveal lithology of the Formations & 2008 \\
\hline 3. & QuickBird satellite image & $60 \mathrm{~cm}$ & Geomorphological Mapping & 2006 \\
\hline 4. & Topographic Map & $1: 100000$ & Urban Mapping & 1971 \\
\hline 5. & Landsat 3 image & $80 \mathrm{~m}$ & Urban Mapping & 1980 \\
\hline 6. & Landsat 5 image & $80 \mathrm{~m}$ & Urban Mapping & 2010 \\
\hline 7. & Landsat 7 image & $30 \mathrm{~m}$ & Urban Mapping & 2017 \\
\hline 8. & Landsat 8 & $30 \mathrm{~m}$ & Urban Mapping & \\
\hline
\end{tabular}

\section{Urban Controlling Factors:}

Several factors affect urban development such as natural, social and economic factors. In the present study the natural factors (geology, geomorphology and climate) are taken into considerations which are controlling urban expansion and growth orientation. 


\section{Geologic Setting:}

The study area is located at the southeastern boundary of high folded zone within the unstable shelf (Jassim and Goff, 2006). Darbandikhan town locates at the trough of a syncline and bounded by three main anticlines; (1) Baranan anticline at northern part, which is extending for more than $50 \mathrm{~km}$ length with nearly $2 \mathrm{~km}$ width; (2) is Bamo anticline located at the eastern part of the study area. It has $30 \mathrm{~km}$ length and $4 \mathrm{~km}$ width; (3) is Qaradagh anticline located at south and southwestern parts that is extending for nearly $10 \mathrm{~km}$ with $2.5 \mathrm{~km}$ width. The study area is occupied by many geological formations of different age as following (Figure 3):

Gercus Formation (Middle Eocene): Lithologically, it consists of red clastic sequence of pinkish red to purple siltstone and claystone alternating with green marl, gray to reddish brown coarse-grained sandstone with conglomerate bed at the bottom of sandstone beds (Bellen, et al., 1959).

Pila Spi Formation (Middle Upper Eocene): The upper part of the formation consists of well bedded, bituminous, chalky and crystalline limestone, with bands of white, chalky marl and with chert nodules towards the top. The lower part shows well bedded hard, porous, bituminous, poorly fossiliferous limestone (Bellen et al., 1959). It is forming the main aquifer in the area.

Fat'ha (Lower Fars) Formation (Middle Miocene): According to Buday (1980) and Jassim and Goff (2006), its lower part composed of alternating thick greenish and reddish silty claystone with thin bedded limestone and thin bedded grayish sandstone. Whereas, the upper part is composed of alternating beds of anhydrite, gypsum and salt, inter bedded with limestone, marl and relatively fine grained clastics. It appears along both limbs of Gulan and Baranan anticlines.

Injana (Upper Fars) Formation (Upper Miocene): Lithologically it, essentially, composed of alternating of mostly red and grey colored silty marlstones, claystone, siltstones of the same color, and medium to coarse grained sandstones (Buday, 1980 and Jassim and Goff, 2006).

Mukdadiya (previously Lower Bakhtiari) Formation (Pliocene): Lithologically, it consists of red clay, sandstone and pebbly sandstone, the size of grains increasing upwards until reaching the massive conglomerate beds of Bai Hassan Formation (Bellen et al., 1959).

Bai Hassan (Upper Bakhtiari) Formation (Pliocene): It mainly consists of coarse and thick fluviatile conglomerate, sandstone and claystone (Bellen et al., 1959). The sediments of quaternary depositss in the folded zone region, are characterized by coarse clastics of mixed gravel and conglomerate intermixed with sand and clay due to the closeness to the source area and the relatively short distance of transportation. Its deposits covering considerable parts of the studied area which include sediments deposited during Pleistocene and Holocene ages that are covering the older rocks in most of the basins. 


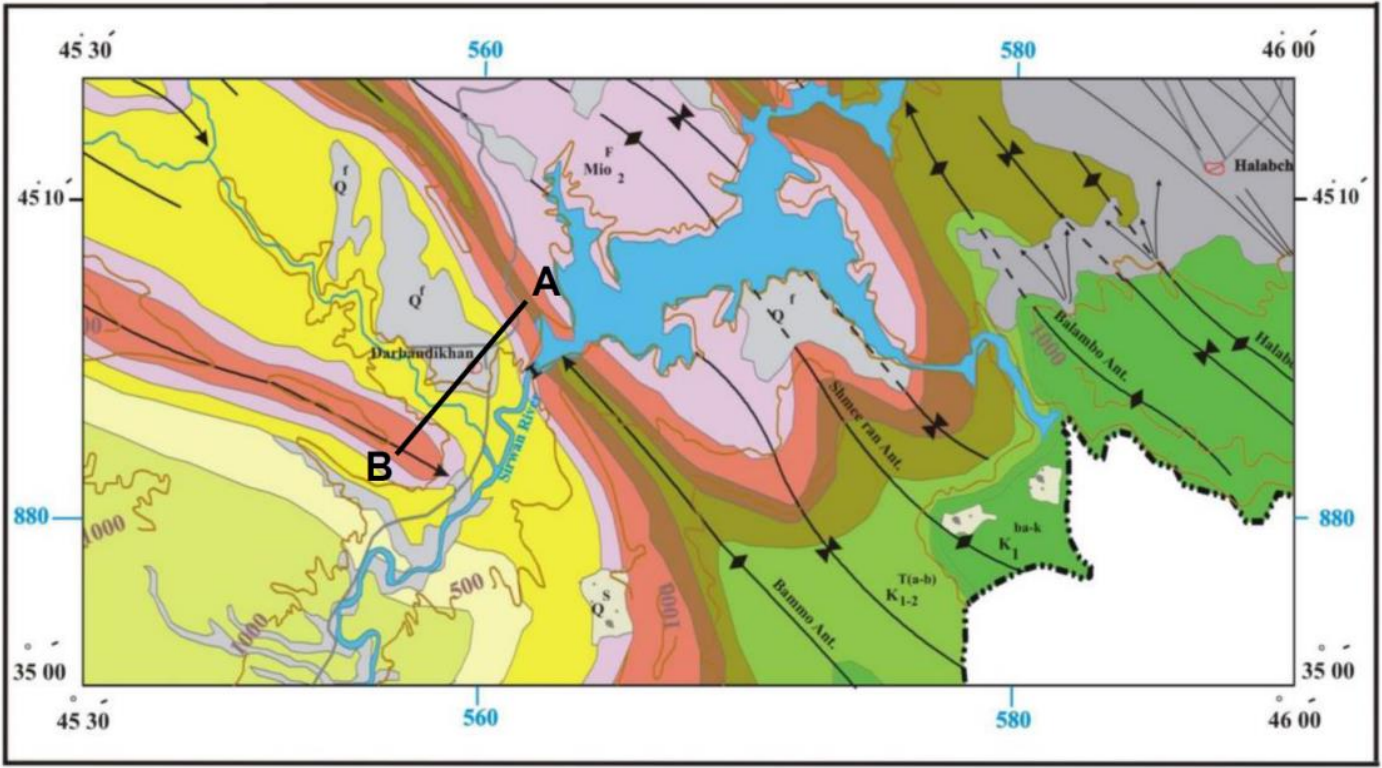

Scale 1:250 000

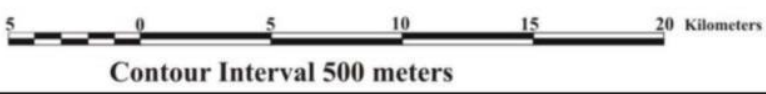

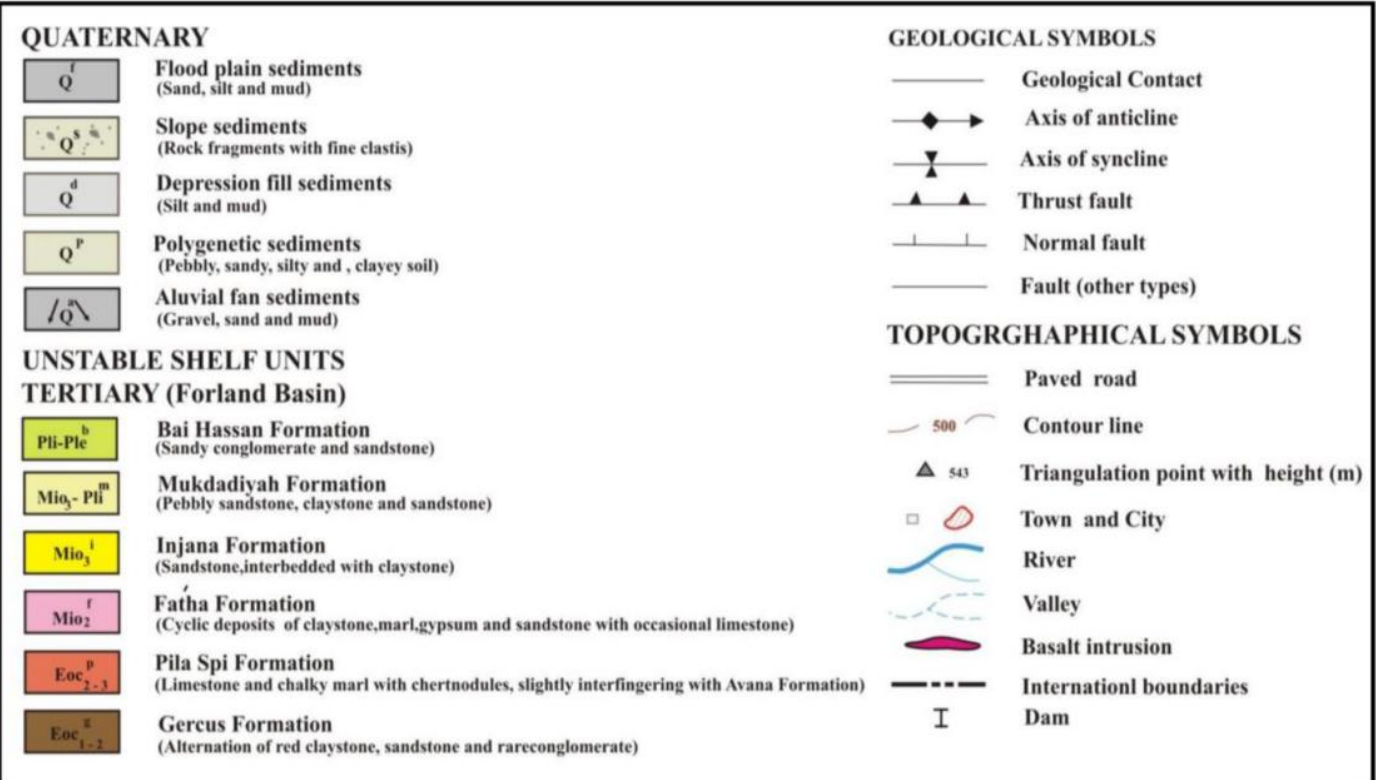

Figure 2: Geological map of the study area (after Ma'ala, 2008).

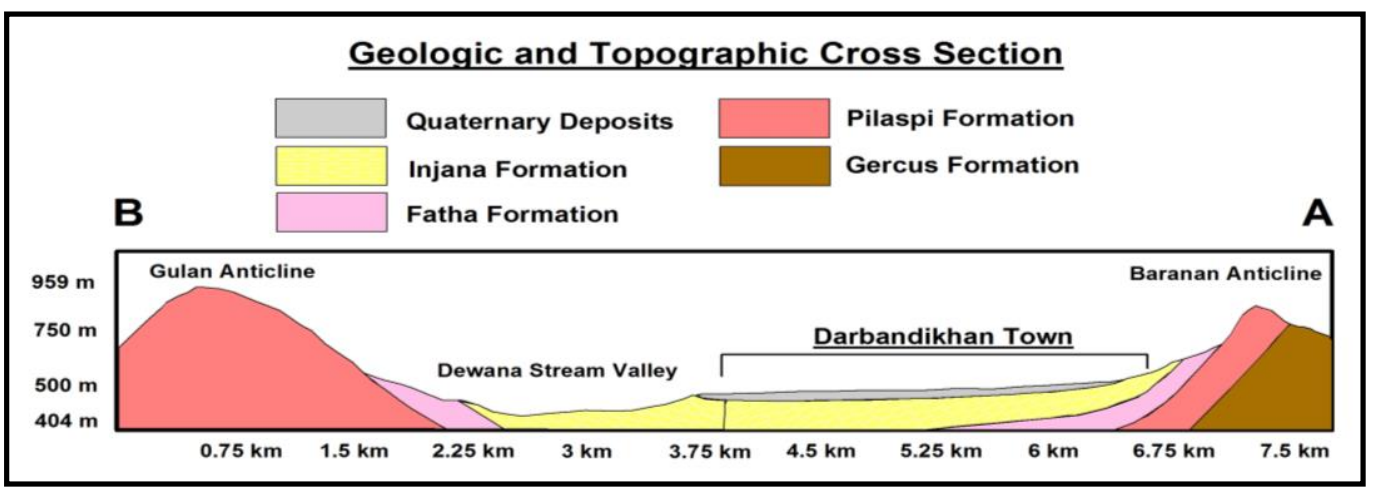

Figure 3: Geological cross section for Darbandikhan Town. 


\section{Climate:}

According to Zavoianu (1985), the evolution of any landscape is a result of interactions between the flows of matter and energy entering and moving within its limits and the resistance of the topographical surface. The interrelationships between these factors and their distributions in time and space govern to a great extent the evolution and the present state of drainage-basin topography.

The area of concern is affected by the Mediterranean and Arabian Gulf climates, which reveals rainfall during winter and spring seasons. Cold winters and long, warm and dry summers are characteristic of the climate in entire area. Autumn and spring are short. Typical semi-arid climatic conditions are prevalent in the plains. Also the climate of the study area classified as sub-humid climate by using De Martonne aridity classification method, whereas Walter-Lieth method reveals six humid months (Figure, 4). According to Köppen climate classification, the study area is falling within (Csa) category, in which climates is mild in winter and hot and dry in summer. The humid period begins in November and ends in April. The mean annual precipitation is $667 \mathrm{~mm}$. This type of climate affects the intensity of geomorphological processes like erosion, weathering and mass wasting.

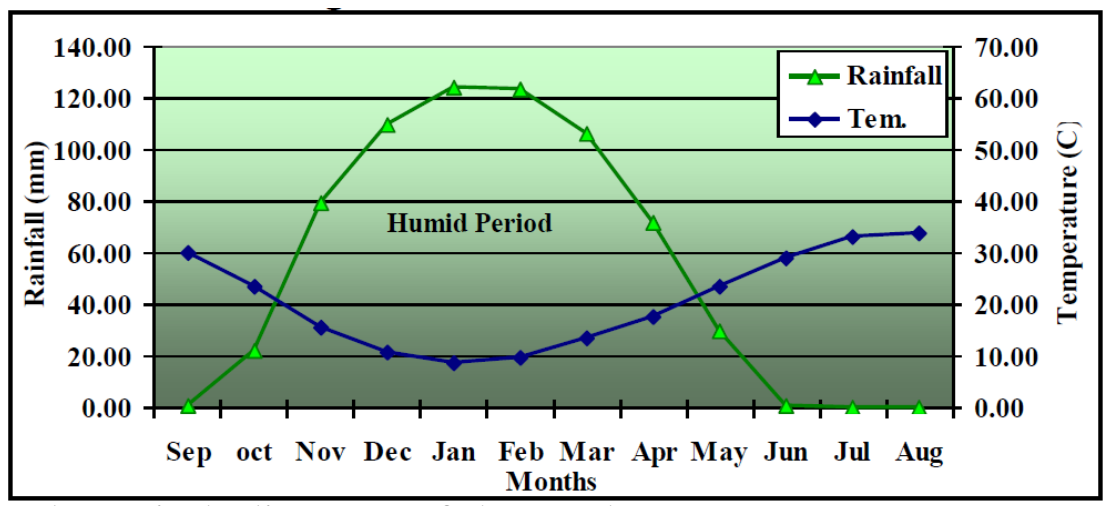

Figure 4: Walter Lieth diagram of the study area.

\section{Geomorphology:}

Darbandikhan district is situated in mountainous ranges of Iraqi Kurdistan Region. The geomorphic processes, which are responsible for landscapes and landforms creation in the present area, are uplifting, folding, fluvial processes, karstification, weathering, erosion, mass wasting, deposition and sedimentation under the influence of gravity and flowing water. The main geomorphic elements of the studied area are elevation, geomorphic units (landforms), slope, and slope aspect and drainage system:

The studied area is characterized by high relief and variable geomorphological properties. The main geomorphological units which have been recognized in the studied area are units of structural origin, units of denudational origin, units of fluvial origin, units of solutional origin and units of anthropogenic origin as shown in Figure 5: 


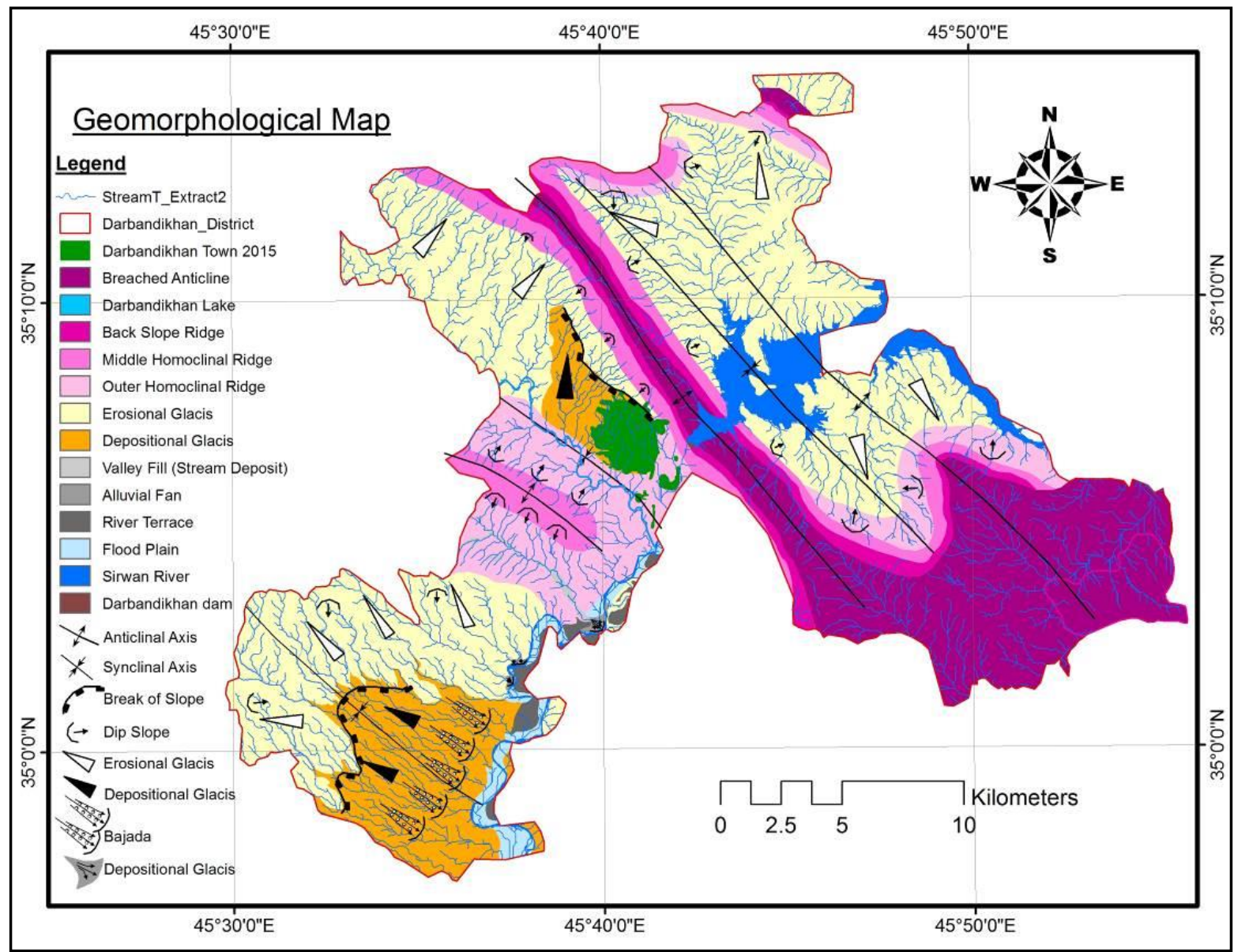

Figure 5: Geomorphological map of the study area.

\section{- Units of Structural Origin}

The tectonic and structural setting affected the spatial distribution of the landform associated with them in the study area. According to Gutiérrez and Gutiérrez (2016) structural landforms are geomorphic features controlled by the underlying geological structure and the distribution of rocks with different resistances to erosion. The landforms which are associated folded and faulted structures in the studied area are: (1) Breached anticlines which appears at the core of the Baranan and Bamo anticlines, which are represented by soft and erodible clastic sedimentary rocks (alternation of sandstone, red siltstone and claystone) of Kolosh and Gercus formations were easily eroded forming anticlines' valley surrounded by hard limestone scarps of Pila Spi Formation. Topographically, it has low elevation than the surrounding beds due to occurrence of extensive deformation at the crest of the folds. (2) Homoclinal ridges or strike ridges, which exist along Baranan and Bamo anticlines that formed due to folding of these structures and down cutting of less resistant rocks. These rocks represented by siltstone and claystone of Fat'ha, Injana and Mukdadiya Formations with a dip between $5^{\circ}$ to more than $70^{\circ}$. The homoclinal ridges include back slope ridges, middle homoclinal ridges and outer homoclinal ridges. 


\section{- Units of Denudational Origin}

The process of denudational origion is playing an important role to create two specific types of landforms which are: (1) Erosional Glacis that are formed by weak materials truncation. They are extending along the middle homoclinal and back slope ridges. (2) Depositional glacises are wide spread landforms mantling lower slope. They consist of truncated weak materials derived from tertiary formations to be deposited and accumulated at foot slope and flanks of the outer homoclinal ridges under the influence of gravitational and fluid forces in the study area, such as talus slope (scree), talus cone, mass wasting materials and alluvium deposits.

\section{- Units of Fluvial Origin}

Fluvial landforms are those generated by running water within Sirwan River and streams in the study area and there are two types of fluvial landforms: (1) Fluvial erosional landforms are generated by the action of flowing water in Sirwan River, Dewan and Daradoin streams with their branches. They cut rills, gullies, river channels and gorge into the bed rocks and spread out all over the study area with variable morphologic characteristic due to spatial variation of lithology, topographic, climatic and vegetation characteristics. Tuni Bawa Umra valleys, Darbandikhan gorge and the bad land along Dewana stream valleys are conspicuous erosional landform in the study area. The flow pattern of Sirwan River encourages erosion and deposition along its meandered course. (2) Fluvial depositional landforms are created by the accumulation of sediments or sculpted on pre-existing material, due to reduction of flowing water within the streams and Sirwan River for carrying materials and including river terraces, alluvial fans, valley fill (stream deposits),

\section{- Units of Solutional Origin}

This type of landform includes small cave, pits and lapis which are formed by karstification of Pilaspi limestone along Gulan, Baranan and Zmnako mountains.

\section{- Units of Anthropogenic Origin}

Anthropogenic landforms are formed by the human activities like excavation, road cuttings, quarries and farming in the study area.

\section{Geomorphic Features:}

\section{- Drainage SYstem}

Drainage density is a measure of the degree of dissection of the drainage basin (McCuen, 1998; Raghunath, 2006; Allan and Castillo, 2007; Huggett, 2007 and Bridge and Demicco, 2008). According to Bathrellos et al. (2012), river and streams are one of the factors that influence potential suitability of landscapes for urban growth. In order to correlate the spatial distribution of drainage network with the urbanization growth, drainage network and drainage density maps had been mapped. Shankar and Mohan (2005) method is used to 
classify stream density to produce a drainage density map in the study area. It was classified into four categories; very low $(0-1)$, low $(1-2)$, medium $(2-$ $3.5)$ and high density (>3.5) as showed in (Figure 6). The drainage density of the study area is ranging from ( $D<1$ to $D>9.3) \mathrm{km} / \mathrm{km}^{2}$. Most of the study area falls under class (3 and 4), which are occupying the down slope area and stream conjunctions.

\section{- Elevation:}

Elevation is an important parameter that affects urban growth. Several investigations have confirmed that elevation is the most important factor, effecting both intensity and distribution of precipitation especially in the mountainous regions (Wright 1962, Taher and Alshaikh 1998; Salar 2013), which effecting intensity and spatial distribution and type of geomorphological processes. According to Bathrellos et al. (2012), areas with high elevation are usually characterized by the absence of vital infrastructure. Darbandikhan district is locating within the mountain range of Iraqi Kurdistan region. It characterizes by existence of wide topographic variety like valley, mountain, hills plain and stream. Darbandikhan Town is surrounded by Baranan Mountain at the north, Zmnako Mountain at the east and Gulan Mountain at southwest. These mountains are separated by deep valleys forming flow paths for Sirwan River at southeast, Dewana and Daradoin streams from southern part. The elevation map is derived from the digital elevation model (DEM) as showed in Figure 6. The elevation of Darbandikhan district is ranging from 359 to $1590 \mathrm{~m}$ a.s.l.. The highest point is located at top of Shameran Mountain east of the studied area, while the lowest point is located at southern part within Sirwan River valley.

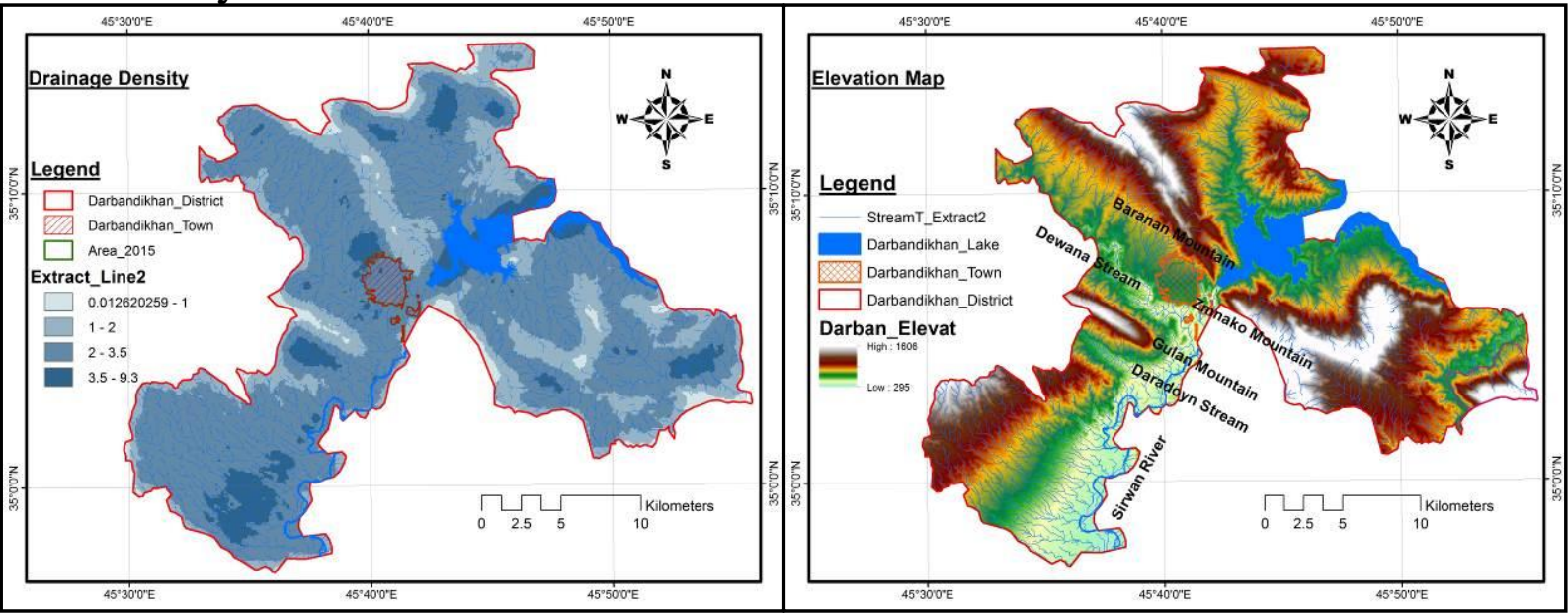

Figure 6: Drainage density and elevation maps of the studied area.

\section{- Slope Gradient:}

The slope of the land surface has a crucial role in the building activity, because steep slopes increase the cost and conduce to erosion intensity (Rao 2005). Moreover, they have an effect on the slope stability, increasing the 
landslide hazard (Bathrellos et al. 2009). In this study, the slope map derived from the DEMa. Youssef et al. (2014) method is used to classify slope map in study area into five classes expressed in degree as showed in Table (2).

The slope map revealed the spatial variation and suitability distribution of slope in the study area: The first class is highly suitable for urban development because it is more stable area that consists of alluvium deposits and mostly forming synclinal valley. The second class is having medium suitability for urbanization. It comprises of bad land and foot slope class with simple curvature. Human activity in this class is less than that of the first class and restricted to some agriculture activity. The suitability of the third and fourth classes is low to very low for urban growth respectively, because they consist of homoclinal ridges and forming low hill and showing more weathering and erosion processes. The final slope class is not suitable for urbanization. It represents homoclinal ridge and central ridge that forming high hills and mountains surrounding Darbandikhan Town. This area is more vulnerable to the denudational process and not suitable for human activities. Hence the areas of very high suitability for urban growth are located mostly at the plain part of the study area that occupies the synclinal valley.

\section{- Slope aspect:}

Panizza (1996) states that slope aspect is one of the main variables that influence the distribution of the Sun's incident rays on a slope at certain latitude and it is obvious that in the northern hemisphere southward slopes are those that most incident to solar radiation. Therefore slope aspect is also taken into account and the study area is classified in to (N, NE, E, SE, S, SW, W, NW) and flat areas, which cannot have a defined orientation (Figure 7). Slope surfaces and constructions with southern and southwestern orientation are exposed to larger amount of sunlight and heat in comparison to other orientation, which means more exposure to weathering processes (thermal action) in this semi-arid area.
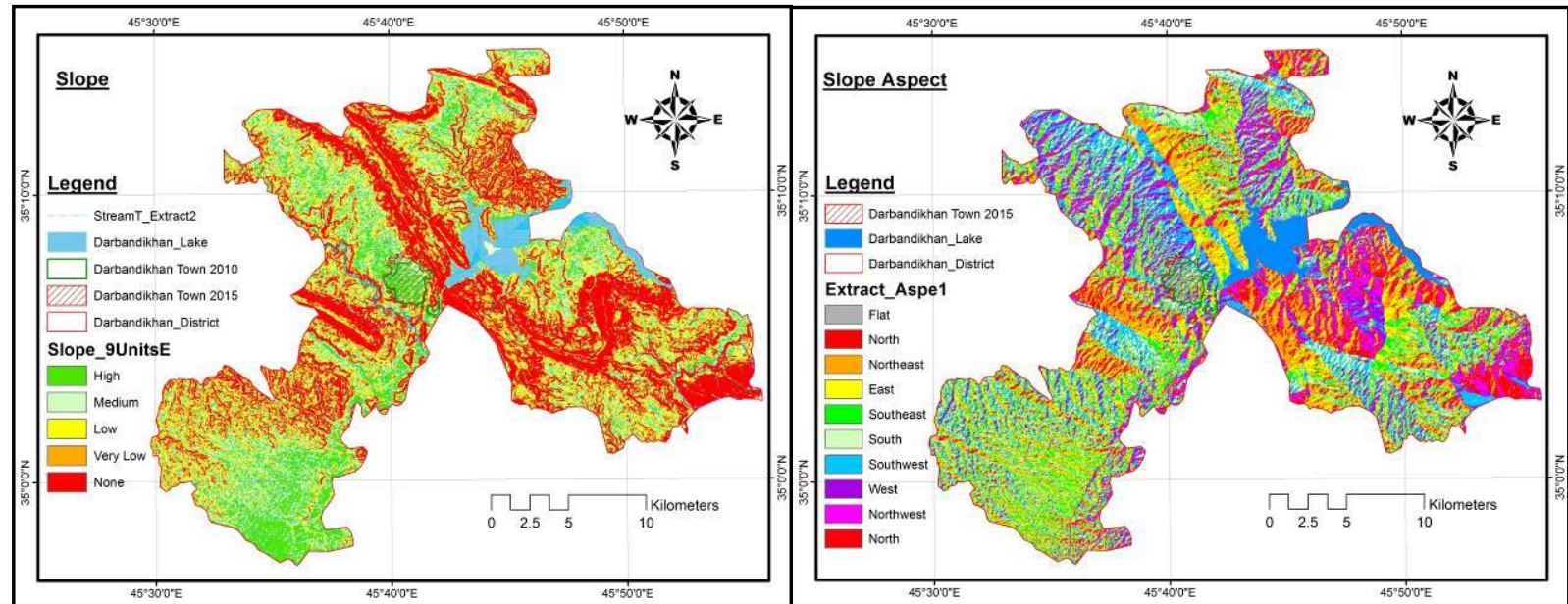

Figure 7: Slope (left) and aspect (right) maps of the studied area. 
Table 2: Slope gradients description in studied area.

\begin{tabular}{|c|c|c|c|l|l|l|}
\hline Slope & Suitability & $\begin{array}{c}\text { Area } \\
\left(\mathbf{K m}^{2}\right)\end{array}$ & $\begin{array}{c}\text { Area } \\
(\boldsymbol{\%})\end{array}$ & \multicolumn{1}{|c|}{ Slope Descriptive } & \multicolumn{1}{|c|}{ Form } & \multicolumn{1}{c|}{ Class } \\
\hline $0-4$ & High & 88.85 & 16.29 & $\begin{array}{l}\text { Old Alluvial Fans/ } \\
\text { Terraces }\end{array}$ & $\begin{array}{l}\text { Valley and } \\
\text { Synclinal Valley }\end{array}$ & Plain \\
\hline $4-8$ & Medium & 109.30 & 20.04 & $\begin{array}{l}\text { Bad Lands/ Foot } \\
\text { Slope }\end{array}$ & $\begin{array}{l}\text { Peni Plain, Foot } \\
\text { Slope }\end{array}$ & Simple Curvature \\
\hline $8-12$ & Low & 88.26 & 16.18 & Homoclinal Ridges & Low Hills & Curvature \\
\hline $12-16$ & Very Low & 77.65 & 14.23 & Homoclinal Ridges & Low Hills & Curvature \\
\hline $16-62.342$ & None & 161.91 & 29.68 & $\begin{array}{l}\text { Homoclinal Ridges } \\
\text { and Central Ridges }\end{array}$ & $\begin{array}{l}\text { High Hills and } \\
\text { Mountains }\end{array}$ & $\begin{array}{l}\text { Isolated to } \\
\text { Highly Dissected }\end{array}$ \\
\hline $\begin{array}{l}\text { Darbandikhan } \\
\text { Lake }\end{array}$ & $/$ & 19.55 & 3.58 & Water body & $/$ & $/$ \\
\hline Total & $/$ & 545.52 & 100 & $/$ & $/$ & $/$ \\
\hline
\end{tabular}

\section{Urban Geomorphology of Darbandikhan Town:}

It is evident from the interpretation and integration of multi-temporal and multi-resolution aerospace data and topographic map that Darbandikhan town has experienced urban growth in the period of 1958 to 2017. The change detection is showed in Figure (8). The natural terrain had been changed to townscape. The processes of urbanization occurred randomly without taking geologic and geomorphic situations into consideration and caused loss of agricultural land. With increasing population year by year, it has become inevitable to choose proper remaining landscape and landforms for urbanization purpose and attain a sustainable environmental stability in Darbandikhan area.

\section{- Temporal Expansion:}

During the past decades, the process of urban growth experienced some high and low speed stages and land has been converted from rural to urban. Figures (8) are showing the past and present urban expansion. While Figures (9) is showing the past, present and future (projected) urban expansion. According to these multi annual changes of urban area, the urban expansion of the town can be divided into four stages. During the first growth stage (1958 - 1980), urban areas grew slowly. The town was initiated its growth, after Darbandikhan's Dam and tunnel construction, form Salim Pirk village at the toe of Baranan Mountain between Darbandikhan's tunnel and the Dam with a slow growth. At the second stage $(1981$ - 1990) the town showed the lowest growth rate. Since 2000, the urban development had a great progression. The other two periods (1991 $2003)$ and (2003 - 2017) can be referred as fast expansion stages. The town expanded from $0.25 \mathrm{~km}^{2}$ in 1958 to $7.229 \mathrm{~km}^{2}$ in 2017 at an average rate of 1.2 $\mathrm{km}^{2} /$ decade. Hence the town expanded exponentially (Figure 9). The projected area of the suitable potential landform for urbanization $15.89 \mathrm{~km}^{2}$ against the extended curve of urban expansion (Figure 9), shows that this suitable area that represented by depositional landform around the town will be consumed in 2028 if the town expansion growth rate continued in its behavior exponentially. 

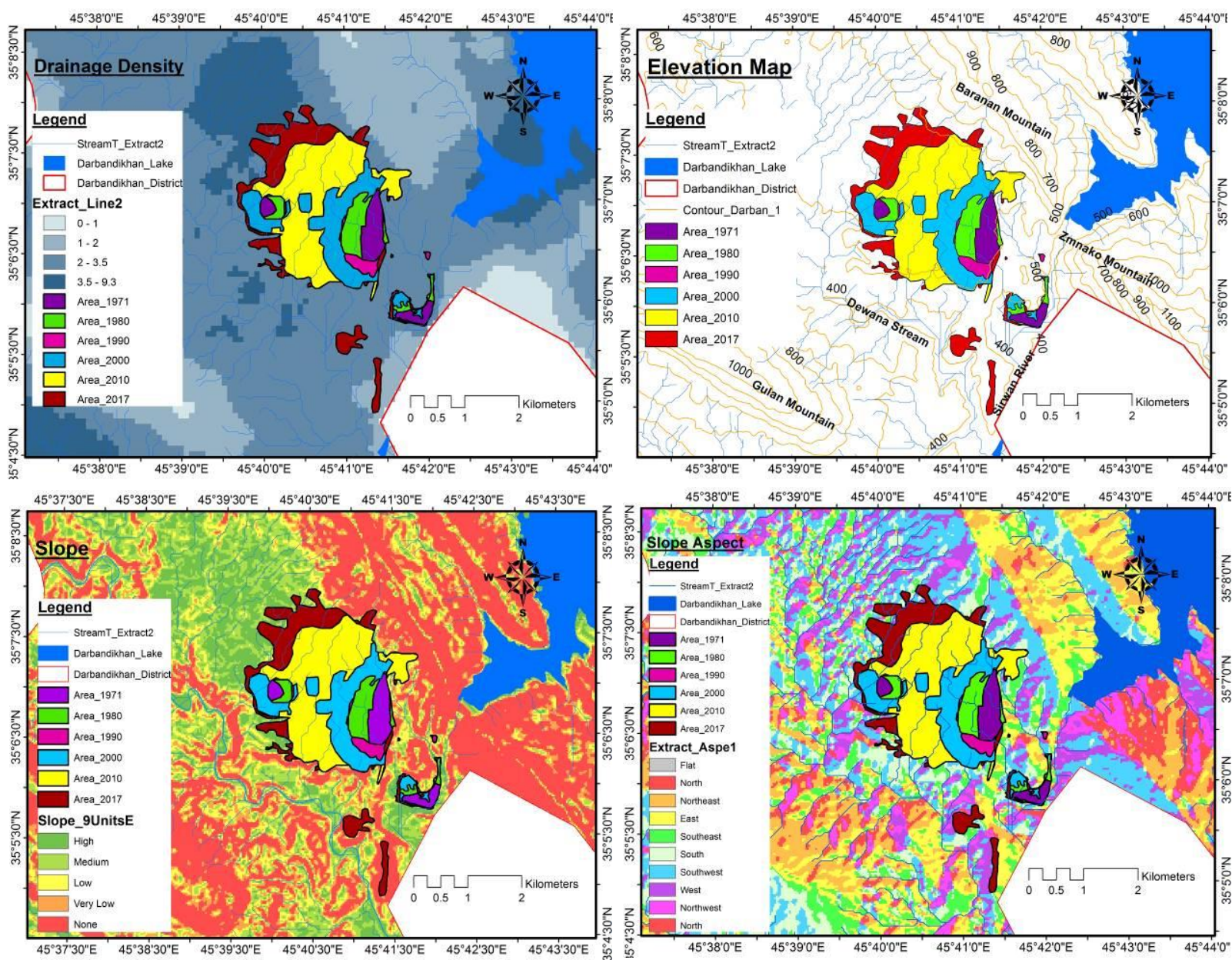

Figure 8: Spatial and temporal urban growth of Darbandikhan Town in relation to lithology landforms, drainage density, elevation and slope

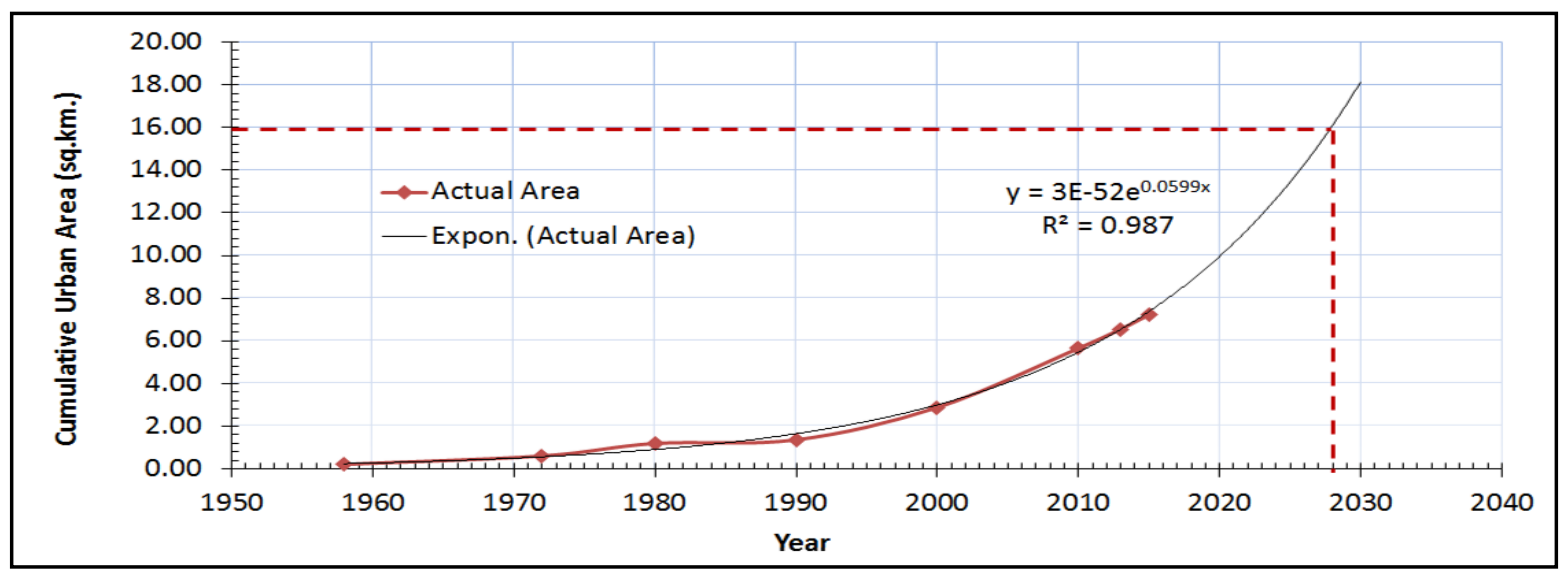

Figure 9: Temporal urban growth of Darbandikhan Town.

\section{- Spatial Expansion:}

The spatial expansion of the urban area, depending on the geologic and geomorphic units, can be evaluated and analyzed on the bases of lithology elevation, slope and landforms: (1) Lithology plays important role on topography and slope stability under the control of differential erosion and weathering processes. According to Panizza (1996) and Blyth and De Freitas 
(2006) lithology commonly of engineering significance to slope stability. The spatial distribution of Darbandikhan town on lithology, showed slight change during the past decades of the town expansion and growth. From 1971 to 2010, the town grew spatially (100\%) on bad sorted mixed alluvium materials of quaternary deposits. Since 2010 the town expansion reached the bed rocks of Injana and Fatha Formations at the southwestern limb of Baranan anticline and became closer to area subjected to degradation and mass wasting processes along the mountain slopes at which the bed rocks are dipping $35^{\circ}$ with dip direction $230^{\circ}$. The sliding and detached rocks from Pila Spi Formation pass over this part. Hence, urbanization in this area is hazardous.

(2) Landforms: The geomorphological map of the study area reveals that Darbandikhan town is occupying landforms of structural and of denudational origins. Urbanization at last years reached outer homoclinal ridge and toe of Baranan Mountain at north and northwest of the town. This landform, on which a part of the town is built on, is not suitable for urbanization purposes, because it subjects to many geomorphic processes like landslide and rock fall which are triggered naturally by rainfall, earthquake and human activities through cutting and excavation. These processes increase the cost and risks.

(3) Drainage density shows runoff potential and landscape dissection, (Macka, 2001). Streams down cutting and dissection of the landform and landscape are observable natural phenomena in the whole study area. Darbandikhan town is falling within the medium drainage density class during the past decades and began to inter the high drainage density class at western and northwestern parts of the town (Figure 8), which means increase of denudation processes intensity and urbanization cost. Youssef et al. (2011), states that they have a negative effect on urban growth because they increase the geomorphic risk, cost and they are restricting areas for urban development.

(4) Elevation: In 1971 the spatial distribution of the urban area was restricted to limited range of elevations. The urban area was extending on elevation ranging from $500-530$ m.a.s.1., whereas in 2017, there was a visible change with that of 1971. Thus the urban growth reached the area of lower and higher elevation. The study area is characterized by high relief. Elevation of Darbandikhan Town ranges from (379 -> 650) $\mathrm{m}$ a.s.l. (Figure, 8). The flat area is separating from Baranan Mountain by contour line $(600 \mathrm{~m})$ at north and northeast of Darbandikhan town, whereas the town is separated from Dewana stream valley by contour line $(500 \mathrm{~m})$ at south. The area below and above elevation $500 \mathrm{~m}$ and $600 \mathrm{~m}$ respectively are not suitable for urban development and expansion (Figure 10). According to Wright (1962), the precipitation increases with increasing of elevation. The elevated area subject the town to hazardous geomorphological processes like mass wasting and fluvial geomorphological processes and economically they increase urbanization cost and Bathrellos et al. (2012), states that the areas with high elevation are usually characterized by the absence of vital infrastructure, such as modern 
transportation networks. This means the higher elevated areas are more exposure to denudational processes and not suitable for urbanization.

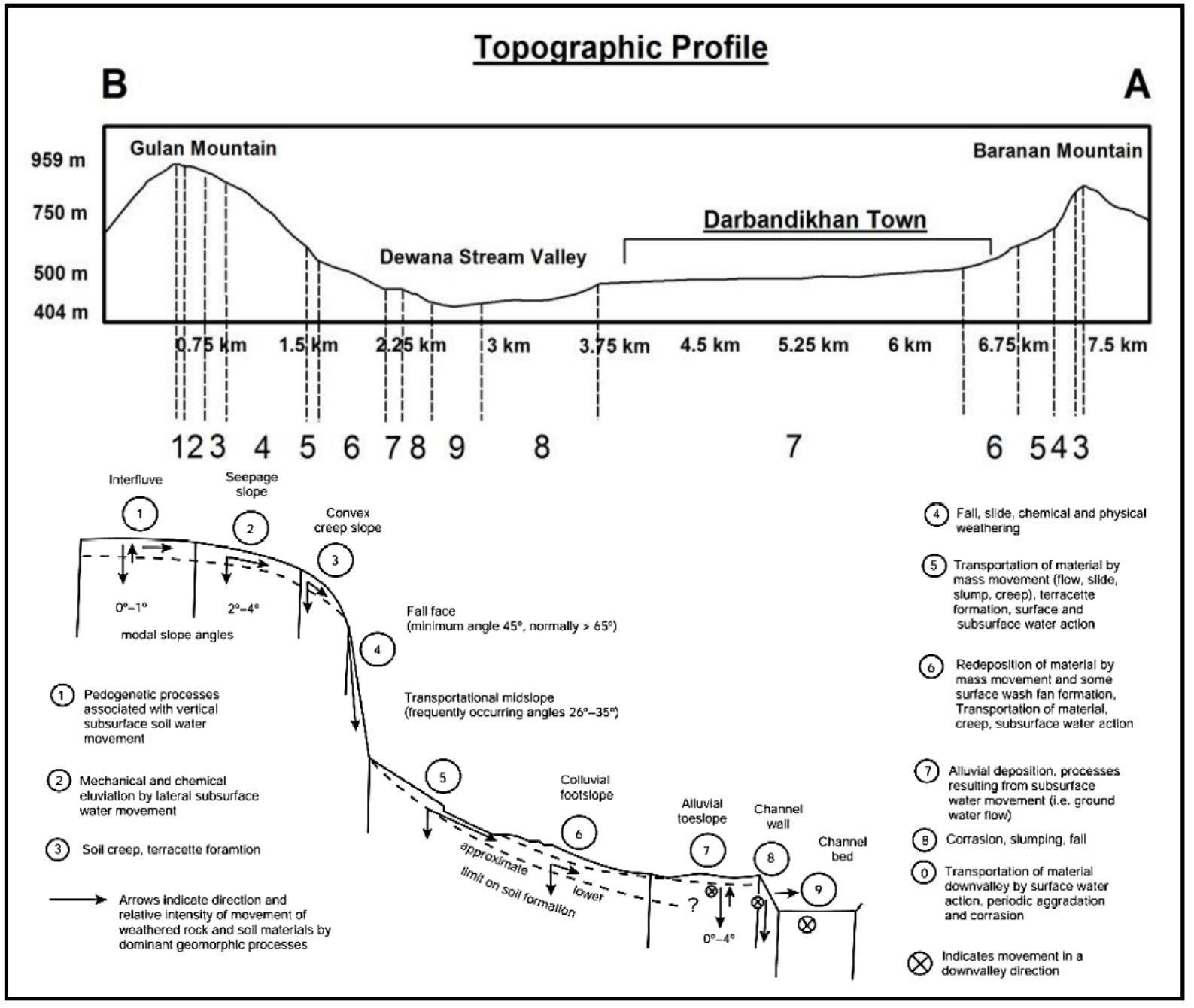

Figure 10: Darbandikhan town on slope profile using Dalrymple et al. (1968) slope model.

(5) Slope: The suitable slope unit for urbanization, along the slope profile, is the lower unit (concave unit) due to occurrence of less geomorphic processes in comparison to the other two slope units. Darbandikhan town had been expanded mostly on the alluvium toe slope units (concave unit) and reached the colluvial foot slope unit, along which many geomorphological processes take place like alluvial deposition, mass movement and some surface wash fan formation, transportation of material, creep, subsurface water action. During 2010 - 2017, the town expansion had been reached steeper slope area and occupying Transportational midslope unit as it shown in Figure 10. Cerreta and P. De Toro (2012) and Youssef et. al, (2014), state that slope more than $\left(16^{\circ}\right)$ are not suitable for urbanization and according to Dalrymple et al. (1968) in Fooke et al. (2007) this slope unit is exposing to processes of material transportation by mass movement (flow, slide, slump, creep), terracette formation, surface and subsurface water action. 


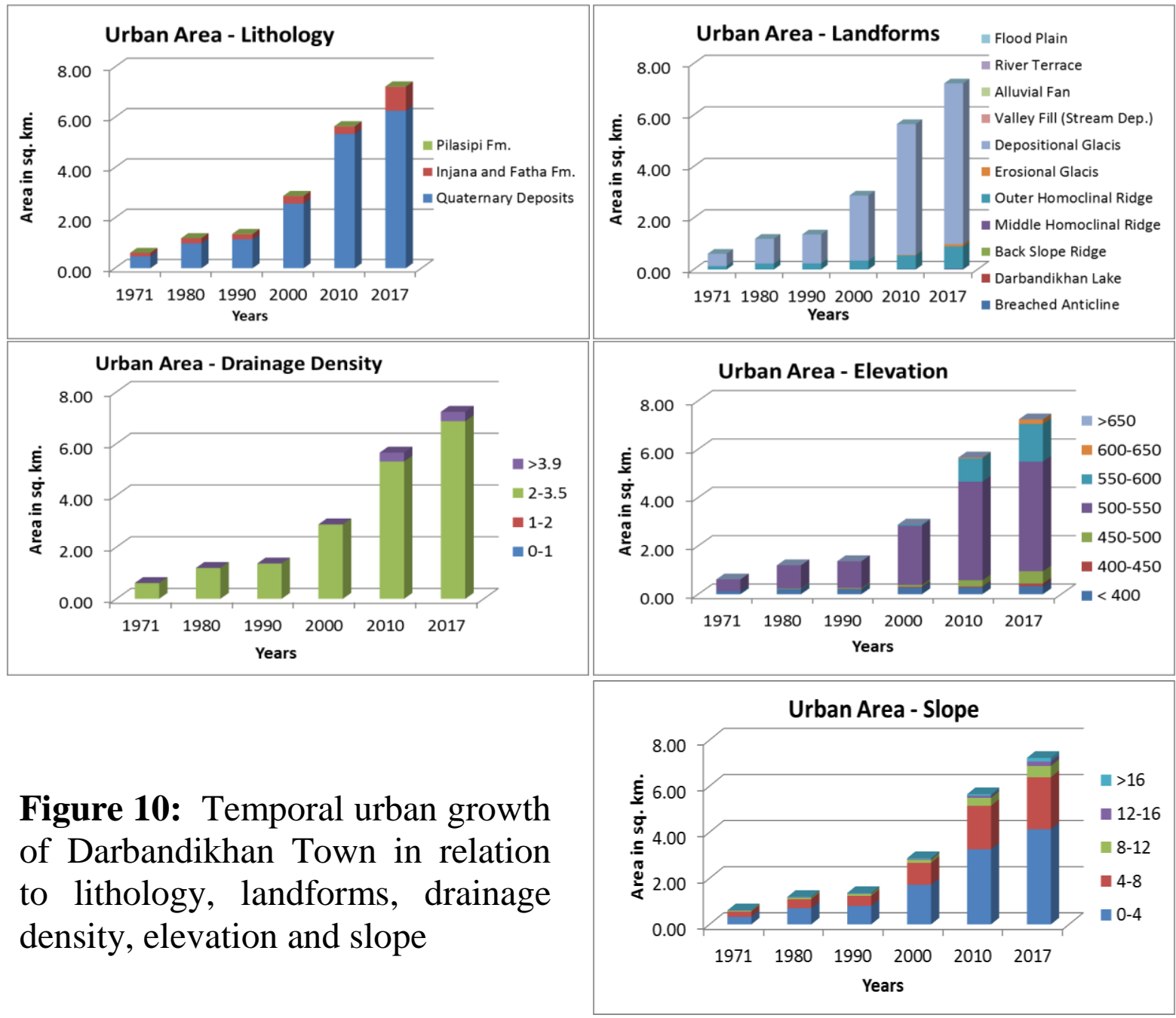

\section{Growth Direction and Future Perspective:}

The past data about Darbandikhan town reveals that the expansion occurred toward west and northwest directions without any other choice. The same pattern of urban growth continued during the subsequent periods in coincide with Darbandikhan synclinal valley, due to existence of many geologic and geomorphological restrictions that act as natural barriers. Baranan anticline at north, northeast and east, Dewana stream at south and southwest and Sirwan River at southeast are the determinatives that restricted the growth direction of the town. Thus the remaining direction for urban growth is westward due existence of suitable landform far from severe hazardous geomorphic processes. According to Fookes et al. (2007) Understanding of geomorphological environments and landscape history, for urban development, can help in identifying and selecting suitable locations for construction. In the present study, the correlation of geology, landform, slope, elevation and drainage system of Darbandikhan District with the urban growth rate and growth direction of the town, are used to evaluate the suitability of the land for urban growth, minimize environmental impact and to provide a local temporal and spatial database that facilitates the prediction of future changes. These factors revealed that the 
suitable area for urbanization is sufficient for incoming $10-20$ years, which is located at west and northwest of the town and composed of flat alluvial landform. Other nearby landform suitable for urbanization purpose is the slight inclined hill slope around Banikhelan village at south of the town with no any else area within Darbandikhan district and administrative boundary. The other areas are consisting of anticlines, eroded synclinal valleys, mountains and highly denudational landscape and landforms forming badland landscapes, which are hazardous and economically highly cost.

\section{Conclusions:}

For the first time, the urban geomorphology for of Darbandikhan district is assessed using quantitative descriptive to study geology, geomorphology and urbanization. Many thematic maps of landforms, drainage system, elevation, slope, slope aspect and drainage density are produced. In addition, the development of the urban pattern and the spatiotemporal changes of urban boundaries in Darbandikhan town from 1971 to 2017 of the study area were performed. In the present study, the following are concluded:

- Geomorphological analysis and classification reveal the occurrence of five geomorphological units based on their origin and they are units of structural origin, units of denudational origin, units of fluvial origin, units of solutional origin, and units of anthropogenic origin.

- Due to geologic and geomorphologic determinatives, Darbandikhan town is expanded westward and northwestward during 1958 - 2017 at an average rate of $1.2 \mathrm{~km}^{2} /$ decade and the expansion reached area not suitable for urbanization at the toe of Baranan anticline in comparison to spatial distribution of landforms, drainage density, elevation, slope and slope aspect.

- At the incoming 10 - 20 years, the total suitable potential area will be consumed if the town expansion growth rate continued in its behavior.

- As a future perspective, the suitable area for urban development is locating at the southern part of the study area

\section{Recommendations:}

The present study provide important information about urban geomorphology of Darbandikhan district for planners, engineers, and decision makers to enhance the results, in order to come up with the most beneficial use of land, along with the conservation of the natural resources and the protection of human lives and environment. Therefore it will be recommended to:

- Build a protection wall along the northern part of Darbandikhan town between urbanized area and toe of Baranan Mountain with gabion, in order to prevent and catch of transported materials by mass movement (flow, slide, slump, and creep)

- Build the buildings and apartments vertically in Darbandikhan town to decrease and lower down the rate of horizontal expansion of the town. 


\section{REFERENCES}

Adeli Z. and Khorshiddoust A., 2011, Application of Geomorphology in Urban Planning: Case study in landfill site selection, Elsevier publ., Procedia Social and Behavioral Sciences Jour., Vol. 19, p 662-667

Allan J. D. and Castillo M. M, 2007, Stream Ecology (Structure and function of running waters), 2nd Edition, Springer, Netherlands, 444p Springer

Allen P. A. and Allen J. R., 2005, Basin Analysis (Principles and Applications), 2nd Ed., Blackwell, Oxford, 562p

Anab R., 2006, Evaluation the risk of erosion in Timgad basin and its impact on Koudiet M'douar Dam - Multi-criterion approaches, unpublished M.Sc. thesis, Department of Geology - College of Science, University of Aqeed Alhaj Lkhdhir - Algeria Republic

Bartl N., Grasemann B., Faber R. and D. Lockhart, 2009, Tectonic geomorphology of the Safeen Anticline (Northern Iraq), Geophysical Research Abstracts, Vol. 11, EGU2009-7626, EGU General Assembly.

Bathrellos G. D., Gaki-Papanastassiou K., Skilodimou H. D., Papanastassiou D., Chousianitis K. G., 2012, Potential suitability for urban planning and industry development using natural hazard maps and geological-geomorphological parameters, Springer Publ., Environ Earth Sci. Vol. 66, p 537-548

Bathrellos G.D., Kalivas D.P., Skilodimou H.D., 2009, GIS-based landslide susceptibility mapping models applied to natural and urban planning in Trikala, Central Greece. Estud Geol, Vol. 65, No. 1, p 49-65

Bell F. G., 2007, Engineering Geology, 2nd Edition, Elsevier Ltd., AMSTERDAM, BOSTON, 593 p.

Bellen R. C., Dunnington H. V., Wetzel R., and Morton D., 1959, Lexique Stratigraphique International, Asie, Iraq, Vol. 3C, 10a, 333p.

Berberian M. and King G. C. P., 1981, Towards a paleogeography and tectonic evolution of Iran, Can Jour. Earth Sci., No. 18, P210-265.

Blyth F. G. H. and de Freitas M. H., 2005, A Geology for Engineers, Elsevier, London, $365 \mathrm{p}$

Bridge J. and Demicco R., 2008, Earth Surface Processes, Landforms and Sediment Deposits, CAMBRIDGE UNIVERSITY PRESS Cambridge, New York, Melbourne, Madrid, Cape Town, Singapore, São Paulo, 835p.

Buday T., 1980, Regional Geology of Iraq, Vol. 1, Stratigraphy, I.I. Kassab and S.Z. Jassim (Eds) D. G. Geo Survey Min. Invest. Publication, 445p.

Burrough P.A., van Gaans P. F. M., MacMillan R.A., 2000, High Resolution Landform Classification Using Fuzzy-k Means, Fuzzy Sets and Systems Vol.113, p37-52.

Cerreta M. and DeToro P., 2012, Urbanization suitability maps: a dynamic spatial decision support system for sustainable land use, Springer, Earth Syst. Dynam. Jour., Vol. 3, p157-171

Cooke, R.U., 1984, Geomorphological Hazards in Los Angeles, London: George Allen and Unwin.

Dalrymple, J. B., Blong, R. J. and Conacher, A. J., 1968, A Hypothetical Nine Unit 
Land Surface Model. Zeitschrift fur Geomorphologie, 12, 60-76

DeVera J., Gines J., Oehlers M., McClay K. and Doski J., 2009, Structure of the Zagros fold and thrust belt in the Kurdistan Region-northern Iraq, jour. of Trabajos de Geología, Universidad de Oviedo, Vol. 29, P 213-217

Fakhari M. D., Axen G. J., Horton B. K., Hassanzadeh J., Amini A., 2008, Revised age of proximal deposits in the Zagros foreland basin and implications for Cenozoic evolution of the High Zagros, Elsevier B.V., Tectonophysics, Tectonophysics, doi:10.1016/j.tecto.2007.11.064

Fookes P. G., Lee E. M. and Griffiths J. S., 2007, Engineering Geomorphology Theory and Practice, Whittles Publishing, Scotland, 293p

Gabler R. E., Petersen J. F., Trapasso L. M., 2007, Essentials of Physical Geography, Eighth Edition, Thomson Brooks, UK, 685p

Goudie A.S.(editor), 2004, Encyclopedia of Geomorphology, Routledge Ltd, Vol. 2

Gutiérrez F. and Gutiérrez M., 2016, Landforms of the Earth (An Illustrated Guide), Springer, Switzerland, 270p

Horton, R. E., 1945, Erosional Development of Streams and Their Drainage Basins Hydrophysical Approach to Quantitative Morphology, Geological Society of America Bulletin, No. 56: 275-370.

Howard A. D, 1997, Badland Morphology and Evolution: Interpretation Using a Simulation Model, John Wiley \& Sons, Ltd, Earth Surface Processes and Landforms and, Vol. 22, 211-227

Huggett R., 2007, Fundamentals of Geomorphology, 2nd edn, Routledge, London, $483 p$

Huggett R., 2010, Physical Geography, First publication, Routledge, London and New York, 225p

Jassim, S. Z, and Goff, J. C., 2006, Geology of Iraq, First edition, Dolin, Prague and Moravian Museum, Brno, Czech Republic, 341p.

Macka Z., 2001, Determination of texture of topography from large scale contour maps, Geografski Vestnik, Vol. 73, NO. 2, p53-62

McCall, G.J.H., De Mulder, E.F.J. and Marker, B.R. (eds), 1996, Urban Geoscience, Rotterdam: Balkema.

McCuen R. H., 1998, Hydrologic Analysis and Design, 2nd Edition, Prentice-Hall Inc, New Jersey, 833p

Mengler F.C., 2008, Gully Erosion on Rehabilitated Bauxite Mine, Unpublished M.Sc. Thesis, University of Western Australia,

Mohapatra S. N., Pani P. and Sharma M., 2014, Rapid Urban Expansion and Its Implications on Geomorphology: A Remote Sensing and GIS Based Study, Hindawi, Geography Jour., Vol. 2014, Article ID 361459, 10p

Numan, N.M.S., 2002, Tectonic investigations in northern Iraq (Report), FAO North Documentation Fund. Erbil (unpublished).

Panda S. K., Sukumar B., 2010, Delineation of Areas for Water Conservation in Peruvamba River basin, Kannur district, Kerala, Using Remote Sensing and GIS, International Journal of Geomatics and Geosciences Vol. 1, No. 1, 8p 
Panizza M., 1996, Environental geomorphology -Elsevier Science B.V. Publication, Developments in earth surface, vol. 4, $268 \mathrm{p}$

Pavlopoulos K., Evelpidou N. and Vassilopoulos A., 2009, Mapping Geomorphological Environments, Springer, London, 236

Raghunath H.M., 2006, Hydrology (Principles, Analysis Design), 2nd Edition, New Age International (P) Ltd., New Delhi, 477p.

Rao K., 2005, Multi-Criteria Spatial Decision Analysis for Forecasting Urban Water Requirements: a Case Study of Dehradun City, India, Landsc Urban Plan Jour., Vol 7, p163-174

Salar S. G., 2013, Geomorphic analysis for Water Harvesting Using GIS Technique in Selected Basins-Garmiyan-Iraqi Kurdistan Region, Sulaimaniyah Univ., Unpublished Ph.D. Thesis, 249p

Shankar M. N. R. and Mohan G., 2005, A GIS Based Hydrogeomorphic Approach for Identification of Site Specific Artificial Recharge Techniques In the Deccan Volcanic Province, Journal of Earth Syst. Sci., Vol. 114, NO. 5, pp. 505-514

Sissakian, V. K., 1993, Geological Map of Iraq, Sheets No.i-38-7, Scale 1:250000, 1st edt. GEOSURV, Baghdad, Iraq.

Sissakian, V. K., 2000, Geological Map of Iraq, Sheets No.1, Scale 1:1000000, 3rd edt. GEOSURV, Baghdad, Iraq.

Stevanovic Z., Iurkiewicz A. and Maran A., 2009, New Insights Into Karst and Caves of Northwestern Zagros (Northern Iraq), Acta Carsologica, Postojna, Vol. 38 No.1, P83-96

Taher S. and Alshaikh A., 1998, Spatial analysis of rainfall in Southwest of Saudi Arabia using GIS, Nordic Hydrol Jour., Vol. 29, No. 2, p91-104

Tucker G. E. and Bras R. L., 1998, Hillslope processes, drainage density, and landscape morphology, Water Resource Research, Vol. 34, No. 10, p 2751-2764.

Tucker G. E. and Slingerland R., 1996, Predicting sediment flux from fold and thrust belts, Jour. of Basin Research, Blackwell Science Ltd 8, 329-349

Wright H. E., 1962, Pleistocene Glaciation in Kurdistan, Eiszeitaller und Gegenwart, Band 12, p131-164.

Young A., 1972, Slopes, London, Longman.

Youssef A. M., Pradhan B., Hassan A. M., 2011, Flash flood risk estimation along the St. Katherine road, southern Sinai, Egypt using GIS based morphometry and satellite imagery, Springer, Environ Earth Sci. Jour., NO. 62, p 611-623

Youssef A. M. \& Pradhan B., Sefry S. A. and Abu Abdullah M. M., (2014) Use of Geological and Geomorphological Parameters in Potential Suitability Assessment for Urban Planning Development at Wadi Al-Aslabasin, Jeddah, Kingdom of Saudi Arabia

Zavoianu I., 1985, Morphometry of Drainage Basin, Elsevier, Amsterdam - Oxford New York, 251pp.

Ziegler M. A., 2001, Late Permian to Holocene Paleofacies Evolution of the Arabian Plate and its Hydrocarbon Occurrences, Gulf PetroLink Bahrain, GeoArabia, Vol. 6, No. 3, 60p. 